\title{
Contribution to the Evaluation of Thermal Insulation Properties of a Simple and a Double Window in a Log building
}

\section{Doprinos procjeni svojstava toplinske izolacije jednostrukoga i dvostrukog prozora na drvenoj kući}

\author{
Preliminary paper • Prethodno priopćenje \\ Received-prispjelo: 6. 3. 2019. \\ Accepted-prihvaćeno: 28. 4. 2020. \\ UDK: $630 * 833.152$ \\ https://doi.org/10.5552/drvind.2020.1915
}

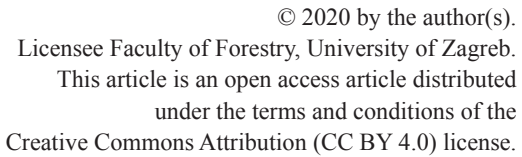

\begin{abstract}
The paper describes the method for the determination and evaluation of thermal insulation properties of various types of windows made from pine wood. The method has been used for a simple and a double window that are parts of a log house in the Czech Republic. Both windows are located in one room. The method for the evaluation of thermal insulation properties consists in determining the boundary conditions of the frame and sash temperature from the interior and exterior. Additionally, the temperature of the window surroundings was measured, at the building envelope. The boundary conditions were measured by different sensors to ensure an accurate setting of the thermographic camera. Based on the values determined, the method calculates the heat transfer coefficient and the temperature factor of the internal surface. Then, the thermal insulation properties of integrated windows can be determined and compared. The priority of this measurement was a basic comparison of thermal insulation properties of two different types of windows located in a log house. This measurement will serve as the basis for a comparison of thermal insulation properties of the same types of windows in different log houses located in regions with different weather conditions. After a comprehensive comparison, based on the results, the right type of window can be recommended with respect to the location of the log house in question.
\end{abstract}

Keywords: simple window; double window; thermal insulation properties; heat transfer

SAŽETAK • U radu je opisana metoda određivanja i procjene svojstava toplinske izolacije različitih tipova prozora od borovine. Metoda je primijenjena za ispitivanje svojstava jednostrukoga i dvostrukog prozora postavljenih na drvenoj kući u Češkoj Republici. Oba se prozora nalaze na istoj prostoriji. Metoda procjene svojstava toplinske izolacije sastoji se od određivanje graničnih uvjeta prozora i doprozornika s unutarnje $i$ vanjske strane. Usto, izmjerena je temperatura oko prozora u ovojnici kuće. Granični su uvjeti izmjereni različitim senzorima kako bi se osigurala točna postavka termografske kamere. Na temelju utvrđenih vrijednosti uz pomoć spomenute metode izračuna se koeficijent prolaska topline i toplinski faktor unutarnje površine. Nakon toga se mogu odrediti i usporediti svojstva toplinske izolacije ugrađenih prozora. Prioritet ovog mjerenja bila je usporedba svojstava toplinske izolacije dvaju različitih tipova prozora na drvenoj kući. Provedeno će mjerenje poslužiti kao osnova

\footnotetext{
Authors are researchers at University of Technology in Brno, Institute of Forensic Engineering, Brno, Czech Republic.

${ }^{2}$ Authors are researchers at Mendel University in Brno, Faculty of Forestry and Wood Technology, Brno, Czech Republic.
} 
za usporedbu svojstava toplinske izolacije istih tipova prozora na različitim drvenim kućama koje se nalaze na lokacijama s različitim vremenskim uvjetima. Nakon složene usporedbe na temelju rezultata može se preporučiti odgovarajući tip prozora s obzirom na lokaciju drvene kuće.

Ključne riječi: jednostruki prozor; dvostruki prozor; svojstva toplinske izolacije; prolazak topline

\section{INTRODUCTION}

\section{UVOD}

A window is an important part of the building external envelope, primarily providing daylight and natural ventilation for the interiors and thus meeting basic health requirements for living spaces (Motyková, 2008). Given the current energy cost increase, house owners wish to improve the energy performance of their houses. This improvement can be continually made throughout the house life. As early as when designing the house and its technical facilities, the climatic conditions of the house location should be taken into account. Disregarding this aspect may lead to significantly increased costs of the house operation. Heat loss of a house can occur through floors, roof, the perimeter wall, doors, and windows. Heat loss through windows is among the largest ones; windows usually represent approximately 30 to 50 percent of the heat loss through the building envelope (Gustavsen, 2011). Therefore, the greatest attention should be paid to window selection, not just from the aesthetic perspective, but mainly with respect to its thermal insulation properties.

When selecting windows, it is especially important to focus on the material of the window frame, as an improved thermal resistance of the frame contributes to the overall energy efficiency of the window. The materials used for the production of window frames include aluminium, metal, composite, fibreglass, vinyl, and wood. Each of these materials has its advantages and disadvantages. Windows in the Czech Republic are typically opened vertically, and they can be simple or double. By a double window, we mean a window of the traditional style with reveal and space in between the panes (Schneck, 2001).

Thermography generally means taking images in wavelengths, which is allowed by the scenographic radiation of the objects measured, in the range from 230 to $310 \mathrm{~K}$ (Hollan, 2005). In contact with the surface measured, the radiation can be absorbed, reflected, or go through the material measured. These ratios are called the absorbance, reflectance, and transmittance (permeability) (Anon, n.d.b). FLIR E60 thermographic camera is intended to be used in civil engineering, offering a higher thermal sensitivity $\left(0.045^{\circ} \mathrm{C}\right)$, and in addition to the common measuring functions (temperature point, area with the minimum, maximum and isotherm localized), it has special measurement functions designed for the building industry. FLIR E60 thermographic camera is suitable for all applications in civil engineering (Anon, n.d.c):

- Localization and extent determination of thermal bridges;

- Checking air tightness of the perimeter envelope;
- Checking the systems of technical installations in buildings;

- Humidity and moisture content issues (ČSN EN ISO 13788:2002).

The aim of this measurement is to be able to recommend the best type of windows for log houses located in different regions with different weather conditions.

\section{MATERIALS AND METHODS} 2. MATERIJALI I METODE

The measurements were carried out in a log house, located in the village of Nasavrky u Chocně, Czech Republic, at an altitude of $345 \mathrm{~m}$. The log building was completed in 2009. Pine timber, $200 \mathrm{~mm}$ thick, was used for its construction. Two types of building windows were measured: a simple window and a double window (Figure 1), pine being the wood species used. Dimensions and parameters of both types of windows were: window size $w \times h-1040 \mathrm{~mm} \times 1300 \mathrm{~mm}$, frame profile $65 \mathrm{~mm} \times 60 \mathrm{~mm}$, sash profile $50 \mathrm{~mm} \times 50$ $\mathrm{mm}$, insulating glass panes $24 \mathrm{~mm}$ thick ( $4 \mathrm{~mm} \times 16$ $\mathrm{mm} \times 4 \mathrm{~mm})$. Sealing in a groove was present along the entire perimeter between the sash and frame. The simple window was double glazed. The double window also had double glazing of both parts - internal and external. The depth of the double window reveal was $100 \mathrm{~mm}$. The windows were installed in the living room, with ground plan proportions of $7.6 \mathrm{~m} \times 3.5 \mathrm{~m}$ and a height of $2.9 \mathrm{~m}$. The mean outside and inside temperatures during the entire measurement were 4.6 ${ }^{\circ} \mathrm{C}$ and $20^{\circ} \mathrm{C}$, respectively. The room is heated by hot air brought into the room through two ceiling vents.

\subsection{Methodology used for thermographic camera} measuring

2.1. Metodologija primijenjena za mjerenje termografskom kamerom

Prior to the measurement done by the thermographic camera, boundary conditions were determined in order to obtain the most precise settings of the camera and avoid inaccuracies of the measurement:

1) Measuring the surface temperature of the measured materials (window frame and the surrounding wall), the measurement was carried out by a predetermined diagram;

2) Measuring the distance of the thermographic camera from the measured materials;

3) Measuring the relative humidity of the measured environment.

\subsection{Methodology for ALMEMO 710 measuring}

2.2. Metodologija mjerenja uređajem ALMEMO 710

The ALMEMO 710 datalogger is a device with 10 inputs for measuring and recording physical quanti- 


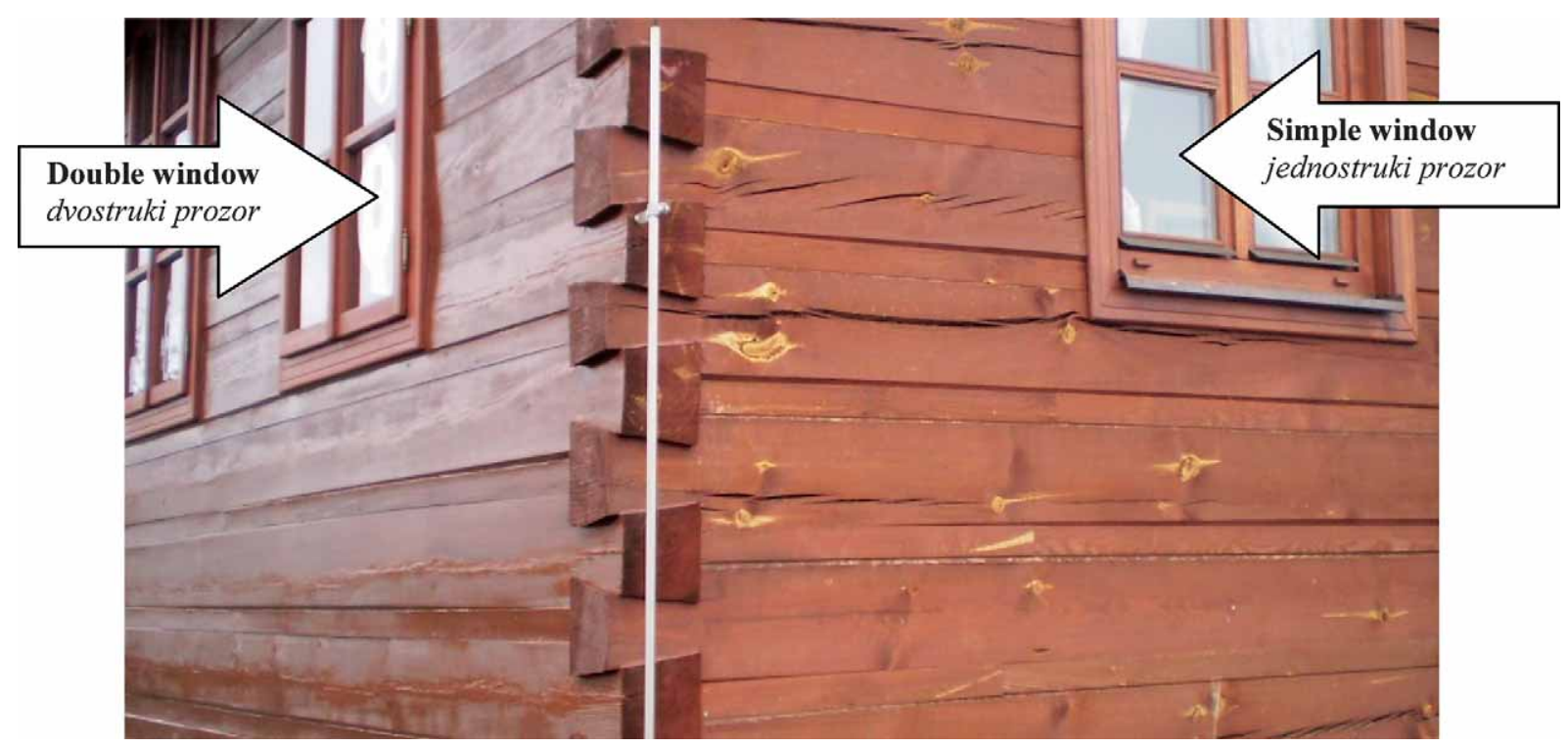

Figure 1 A view of simple and double windows from the exterior Slika 1. Pogled na jednostruki i dvostruki prozor s vanjske strane

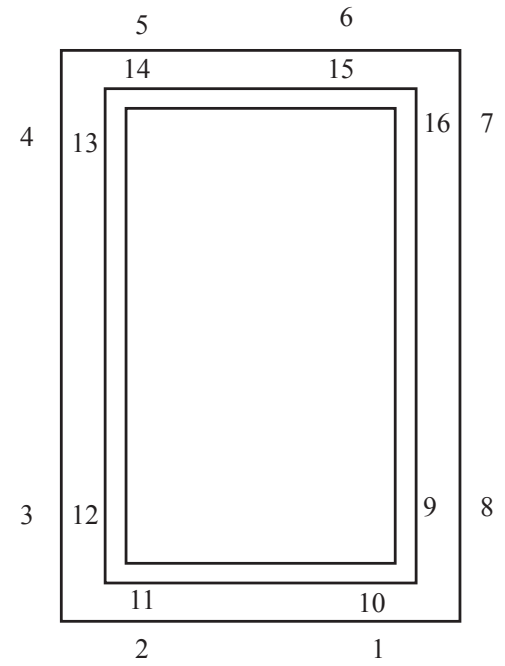

Figure 2 Marks for temperature measurement of windows in the interior

Slika 2. Oznake mjesta mjerenja temperature na prozoru s unutarnje strane

ties that can be displayed on the colour display in numerical form, in line and column charts with a record in the internal memory with an output to PC (Anon, n.d.d). The measurements were conducted for a week for each window individually. To make the measurement as precise as possible, 2005 individual values were recorded in 10-minute intervals. Before the measuring of the windows by ALMEMO 710, it was necessary to determine appropriate locations and locate the device and its sensors:

- A sensor measuring relative humidity and air temperature (type: FHAD 46-2) - A sensor measuring relative humidity and air temperature located in the window interior;

- A sensor measuring relative humidity and air temperature (type: FHA646-1) - A sensor measuring relative humidity and air temperature located in the window exterior;
- Temperature sensor (type: FPA686) - A foil sensor measuring the surface temperature located on the window sash in the interior;

- Temperature sensor (type: FPA686) - A foil sensor measuring the surface temperature located on the window frame in the exterior.

\subsection{Calculation of heat transfer coefficient, $U$}

2.3. Izračunavanje koeficijenta prolaska topline, $U$

The measurement of heat transfer coefficient through windows integrated in buildings is not exactly described and established in any regulation. The only measurement method based on specified regulations is the measurement in a laboratory under set conditions of the surrounding environment, which mainly serves for the determination of standards for window manufacturers (Černíková, 2012). An alternative way for the calculation of thermal efficiency of window frames is to use 2D numerical simulations, which can be used for a comparison with the values measured in integrated windows (Bossche, 2015; Baldinelli, 2014).

The calculation of thermal efficiency of window frames can be done by 2D numerical simulations (Bossche et al., 2015). The basic calculation of heat transfer coefficient, U, was conducted based on ( $\breve{C S N}$ EN ISO 10077-1:2007). As a complex transfer coefficient of the entire window had to be measured, we chose the method based on the calculation of the heat transfer coefficient, $\mathrm{U}$, on the frame and sash of each evaluated window and the following comparison of the thermal insulation properties of the windows, using the formula:

$$
\begin{gathered}
U=\alpha_{\mathrm{i}} \frac{\Delta T_{1}}{\Delta T_{2}} \\
\Delta T_{1}=T_{\mathrm{i}}-T_{\mathrm{WK}, \mathrm{WR}} \\
\Delta T_{2}=T_{\mathrm{i}}-T_{\mathrm{e}}
\end{gathered}
$$

Where

$T_{\mathrm{i}}$ - interior air temperature $\left({ }^{\circ} \mathrm{C}\right)$ 
$T_{\mathrm{e}}$ - exterior air temperature $\left({ }^{\circ} \mathrm{C}\right)$

$T_{\mathrm{wK}}$ - surface temperature of internal window sash $\left({ }^{\circ} \mathrm{C}\right)$

$T_{\mathrm{WR}}$ - surface temperature of internal window frame $\left({ }^{\circ} \mathrm{C}\right)$

$\alpha_{\mathrm{i}}$ - a constant $7.69 \mathrm{~W} / \mathrm{m}^{2} \mathrm{~K}$

The method is based on the parallel measuring of the interior air temperature $T_{\mathrm{i}}$ by a measuring device, measuring of the temperature of the internal surface of the structure by $T_{\mathrm{w}}$ probes and measuring of the exterior air temperature $T_{\mathrm{e}}$ by a radio probe. The three temperatures are used together with constant $\alpha_{\mathrm{i}}=7.69 \mathrm{~W} /$ $\mathrm{m}^{2} \mathrm{~K}$ (Anon, n.d.e 2011) to calculate the heat transfer coefficient, $U$, by the following formula:

$$
\alpha_{\mathrm{i}}=\frac{q}{T_{\mathrm{W}}-T_{\mathrm{i}}}
$$

\subsection{Calculation of internal surface temperature} factor, $f_{\text {Rsi }}$

2.4. Izračunavanje toplinskog faktora unutarnje površine, $f_{\mathrm{Rs}}$

It is important to determine in winter the internal surface temperature factor, $f_{\text {Rsi }}$, especially at joints and places with an uneven insulation of the structure, as moisture can be condensed and mould can occur. The internal surface temperature factor, $f_{\mathrm{Rsi}}$, which is the ratio of the difference of the internal surface temperature to the external air temperature and the difference of the internal air temperature to the external air temperature, can be calculated using two equations (ČSN 730540 2:2002):

$$
f_{\mathrm{Rsi}}=\frac{\theta_{\mathrm{si}}-\theta_{\mathrm{e}}}{\theta_{\mathrm{ai}}-\theta_{\mathrm{e}}}=1-\frac{\theta_{\mathrm{ai}}-\theta_{\mathrm{si}}}{\theta_{\mathrm{ai}}-\theta_{\mathrm{e}}}
$$

$$
f_{\mathrm{Rsi}}=1-U_{\mathrm{x}} \cdot R_{\mathrm{si}}
$$

Where

$\theta_{\text {si }}$ - internal surface temperature of the structure $\left({ }^{\circ} \mathrm{C}\right)$

$\theta_{\mathrm{e}}^{\mathrm{s} 1}$ - external air temperature $\left({ }^{\circ} \mathrm{C}\right)$

$\theta_{\text {ai }}^{\mathrm{e}}$ - internal air temperature $\left({ }^{\circ} \mathrm{C}\right)$

$\theta_{\mathrm{x}}$ - local heat transfer coefficient at place $\mathrm{x}$ of internal surface $\left(\mathrm{W} / \mathrm{m}^{2} \mathrm{~K}\right)$

$\theta_{\mathrm{si}}$ - resistance during heat transfer on internal side of the structure and, in compliance with ČSN EN ISO 13788 , it has a value of $0.25 \mathrm{~m}^{2} \mathrm{~K} / \mathrm{W}$ (Slanina, 2012).

\section{RESULTS AND DISCUSSION 3. REZULTATI I RASPRAVA}

The results of the measuring with the thermographic camera are presented in Table 1 and 2 and in Figure 3 and 4.

The measured values show that the double window has significantly better thermal insulation properties than the simple window. The values presented in Table 1 and 2 indicate that the mean temperature difference between these windows is $1.5^{\circ} \mathrm{C}$, which can cause a significant heat loss in the log building given its total number of windows.

The images show the largest heat losses in the simple window in the space between the window frame and its sash (black spectrum). The heat loss is not so apparent in the double window, which is indicated by the light spectrum of the image. This is caused by the sufficient air insulation between the internal and exter-

\begin{tabular}{|c|c|c|c|}
\hline $\begin{array}{l}\text { Measuring no. } \\
\text { Broj mjerenja }\end{array}$ & $\begin{array}{l}\text { Wall temperature, }{ }^{\circ} \mathbf{C} \\
\text { Temperatura zida, }{ }^{\circ} \mathrm{C}\end{array}$ & $\begin{array}{c}\text { Frame temperature, }{ }^{\circ} \mathrm{C} \\
\text { Temperatura okvira, }{ }^{\circ} \mathrm{C} \\
\end{array}$ & $\begin{array}{c}\text { Difference in temperatures, }{ }^{\circ} \mathrm{C} \\
\text { Razlika u temperaturama, }{ }^{\circ} \mathrm{C}\end{array}$ \\
\hline $1-10$ & 18.7 & 17.1 & 1.6 \\
\hline $2-11$ & 19.0 & 17.0 & 2.0 \\
\hline $3-12$ & 18.8 & 17.4 & 1.4 \\
\hline $4-13$ & 19.2 & 17.8 & 1.4 \\
\hline $5-14$ & 20.4 & 19.2 & 1.2 \\
\hline $6-15$ & 21.2 & 19.6 & 1.6 \\
\hline $7-16$ & 22.0 & 19.0 & 3.0 \\
\hline $8-9$ & 19.4 & 17.3 & 2.1 \\
\hline $\begin{array}{c}\text { Arith. mean } \\
\text { Srednja vrijednost }\end{array}$ & 19.8 & 18.5 & 1.8 \\
\hline
\end{tabular}

Table 1 Temperatures measured in a simple window interior

Tablica 1. Temperature izmjerene na jednostrukom prozoru s unutarnje strane

Table 2 Temperatures measured in a double window interior

Tablica 2. Temperature izmjerene na dvostrukom prozoru s unutarnje strane

\begin{tabular}{|c|c|c|c|}
\hline $\begin{array}{c}\text { Measuring no. } \\
\text { Broj mjerenja }\end{array}$ & $\begin{array}{c}\text { Wall temperature, }{ }^{\mathbf{0}} \mathbf{C} \\
\text { Temperatura zida, }{ }^{\circ} \mathrm{C}\end{array}$ & $\begin{array}{c}\text { Frame temperature, } \\
\text { Temperatura } \text { okvira, }{ }^{\circ} \mathrm{C}\end{array}$ & $\begin{array}{c}\text { Difference in temperatures, }{ }^{\mathbf{0}} \mathbf{C} \\
\text { Razlika } u \text { temperaturama, }{ }^{\circ} \mathrm{C}\end{array}$ \\
\hline $1-10$ & 20.0 & 19.6 & 0.4 \\
\hline $2-11$ & 19.9 & 19.6 & 0.3 \\
\hline $3-12$ & 20.2 & 19.9 & 0.3 \\
\hline $4-13$ & 22.1 & 21.8 & 0.3 \\
\hline $5-14$ & 22.8 & 22.5 & 0.3 \\
\hline $6-15$ & 22.4 & 22.2 & 0.2 \\
\hline $7-16$ & 22.2 & 22.1 & 0.1 \\
\hline $8-9$ & 20.6 & 20.3 & 0.3 \\
\hline Arith. mean \\
Srednja vrijednost
\end{tabular}




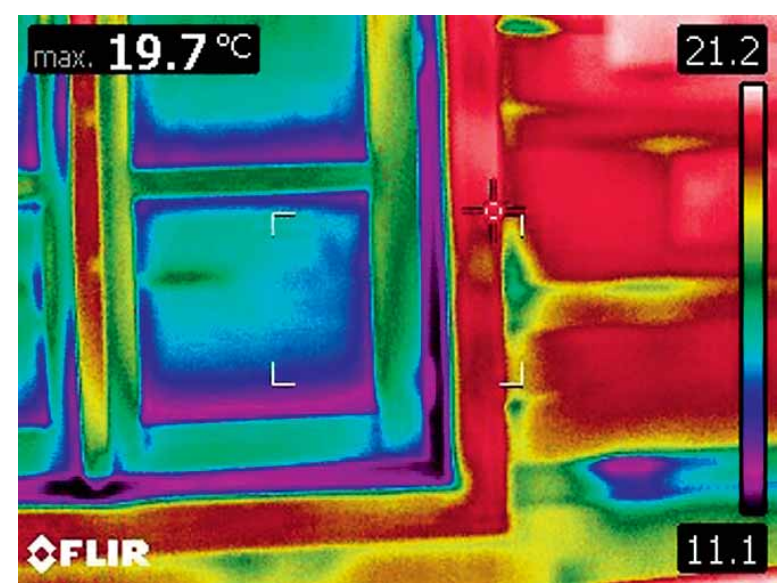

Figure 3 Image of a simple window

Slika 3. Termografska slika jednostrukog prozora

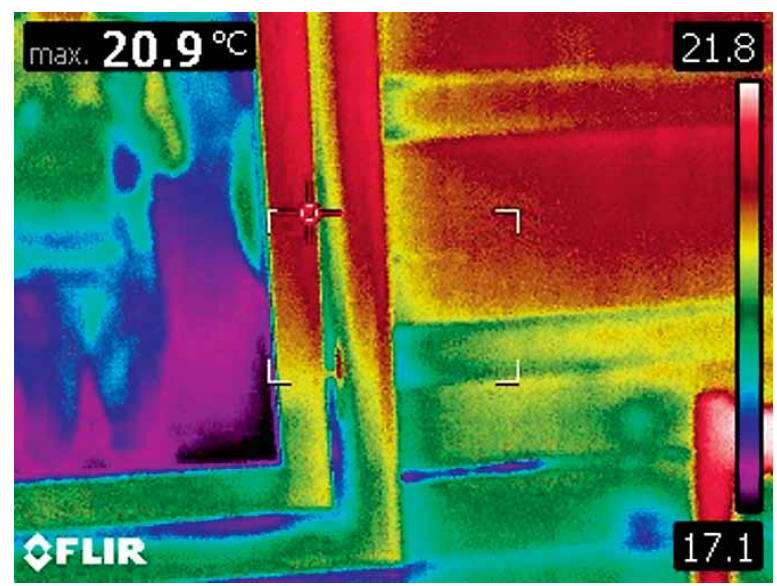

Figure 4 Image of a double window

Slika 4. Termografska slika dvostrukog prozora

Table 3 Heat transfer coefficient, $U_{\mathrm{N}}$

Tablica 3. Koeficijent prolaska topline, $U_{\mathrm{N}}$

\begin{tabular}{|c|c|c|c|c|}
\hline $\begin{array}{c}\text { Day } \\
\text { Dan }\end{array}$ & $\begin{array}{c}\text { U-Simple-sash } \\
\text { U-jednostruki doprozornik }\end{array}$ & $\begin{array}{c}\text { U-Simple-frame } \\
\text { U-jednostruki okvir }\end{array}$ & $\begin{array}{c}\text { U-double-sash } \\
\text { U-dvostruki doprozornik }\end{array}$ & $\begin{array}{c}\text { U-double-frame } \\
\text { U-dvostruki okvir }\end{array}$ \\
\hline 1 & 2.8 & 1.4 & 0.3 & 0.3 \\
\hline 2 & 2.4 & 1.2 & 0.6 & 0.6 \\
\hline 3 & 1.9 & 0.8 & 0.6 & 0.6 \\
\hline 4 & 1.8 & 0.8 & 0.7 & 0.7 \\
\hline 5 & 1.5 & 0.8 & 0.8 & 0.6 \\
\hline 6 & 1.6 & 0.7 & 0.8 & 0.7 \\
\hline 7 & 2.6 & 1.3 & 0.7 & 0.7 \\
\hline $\begin{array}{c}\text { Arith. mean } \\
\text { Srednja vrijednost }\end{array}$ & 2.2 & 1.0 & 0.7 & 0.7 \\
\hline
\end{tabular}

nal window panes. The values of heat transfer coefficient calculated, $U_{\mathrm{N}}$, are presented in Table 3.

The surrounding factors have a significant effect on the different values of the heat transfer coefficient:

- Temperature of external environment;

- Intensity of sunlight;

- Air velocity in exterior and interior;

- Relative air humidity in exterior and interior.

The values measured were compared with the values demanded related to the standard applicable in the Czech Republic - ČSN 730540-2, which establishes the standard values of the heat transfer coefficient, $U_{\mathrm{N}}\left(\mathrm{W} / \mathrm{m}^{2} \mathrm{~K}\right)$.

- Values required $U_{\mathrm{N} 20} 1.50\left(\mathrm{~W} /\left(\mathrm{m}^{2} \mathrm{~K}\right)\right.$
- Values recommended $U_{\mathrm{N} 20} 1.20\left(\mathrm{~W} / \mathrm{m}^{2} \mathrm{~K}\right)$

- Values recommended for passive buildings $U_{\mathrm{N} 20} 0.80$ $\left(\mathrm{W} / \mathrm{m}^{2} \mathrm{~K}\right)$.

The heat loss in the simple window is considerable and the window efficiency is so low that, from the economic point of view, the simple window should be replaced with a double one. The calculated values of the internal surface temperature factor, $f_{\mathrm{Rsi}}$, are presented in Table 4.

After calculating the internal surface temperature factors of the frames and sashes and comparison with the table of temperatures corresponding to the critical factor of the internal surface, the frames of both windows, simple and double, comply with ČSN 730540-2

Table 4 Critical factor for internal surface temperature, $f_{\mathrm{Rsi}}$ Tablica 4. Kritični toplinski faktor unutarnje površine, $f_{\mathrm{Rsi}}$

\begin{tabular}{|c|c|c|c|c|}
\hline \multirow{2}{*}{$\begin{array}{c}\text { Day } \\
\text { Dan }\end{array}$} & \multicolumn{4}{|c|}{$\begin{array}{c}\text { Critical factor for internal surface temperature, } \boldsymbol{f}_{\mathrm{Rsi}} \\
\text { Kritični toplinski faktor unutarnje površine, } f_{\text {Rsi }}\end{array}$} \\
\cline { 2 - 5 } & $\begin{array}{c}\text { Simple window sash } \\
\text { Jednostruki doprozornik }\end{array}$ & $\begin{array}{c}\text { Simple window frame } \\
\text { Jednostavni okvir }\end{array}$ & $\begin{array}{c}\text { Double window sash } \\
\text { Dvostruki doprozornik }\end{array}$ & $\begin{array}{c}\text { Double window frame } \\
\text { Dvostruki okvir }\end{array}$ \\
\hline 1 & 0.30 & 0.65 & 0.93 & 0.93 \\
\hline 2 & 0.40 & 0.70 & 0.85 & 0.85 \\
\hline 3 & 0.53 & 0.80 & 0.85 & 0.85 \\
\hline 4 & 0.56 & 0.80 & 0.83 & 0.83 \\
\hline 5 & 0.63 & 0.80 & 0.80 & 0.85 \\
\hline 6 & 0.60 & 0.83 & 0.80 & 0.85 \\
\hline 7 & 0.35 & 0.68 & 0.83 & 0.83 \\
\hline Arith. mean & 0.48 & 0.75 & 0.84 & 0.86 \\
\hline Srednja vrijednost & & & & \\
\hline
\end{tabular}


requirements. The mentioned standard, ČSN 730540-2, was used for experimental measuring at the time when this study was processed, so it would be recommendable to use it again for the measurements of other log buildings in order to obtain comparable results. The temperature of the internal surface critical factor of the double window sash is compliant; in contrast, the simple window sash does not meet the requirements.

\section{CONCLUSIONS}

\section{ZAKLJUČAK}

Windows are the weakest spot of each building envelope from the perspective of thermal insulation properties and thus the economic performance of log houses. The aim of this study was to obtain values that will allow for a basic comparison of thermal insulation properties of two different types of windows located in the same $\log$ building. This measurement will serve as a basis for a more complex comparison of thermal insulation properties of the same types of windows in other log buildings located in regions with different weather conditions. The advantages of the method used are mainly the exact recording of measured values in exact sequences, possible recording of window opening and closing during the measurement process, and the consequent exclusion of these data from the evaluation in order to eliminate errors. Another advantage is that the method is simple and cheap. A drawback was the necessity to measure each window separately because we do not have a sufficient amount of measuring devices to measure them at the same time. According to ČSN 730540-2 the frame of the simple window with a measured mean of $0.80 \mathrm{~W} / \mathrm{m}^{2} \mathrm{~K}$ meets even the value recommended for passive buildings; the sash of the simple window with a measured mean of $2.20 \mathrm{~W} / \mathrm{m}^{2} \mathrm{~K}$ does not meet any of the required or recommended values. Generally, the simple window does not meet the thermal transmission coefficient requirements of ČSN 730540-2. In contrast, the frame and sash of the double window with a mean of $0.70 \mathrm{~W} / \mathrm{m}^{2} \mathrm{~K}$ meet the values recommended for passive buildings, based on ČSN 730540-2. Generally, the double window meets the thermal transmission coefficient requirements of ČSN 730540-2. The measured values show that the greatest heat loss occurs in the sash of the simple window. The measurement of thermal insulation properties of windows indicates that, in order to improve the energy performance of a building, it is necessary to consider boundary conditions of the building environment before selecting the specific type of windows.

\section{REFERENCES}

\section{LITERATURA}

1. Anon. n.d.e: ALMEMO Manual, 9. Edition 2011: Measuring heat flow.

2. Anon. n.d.c: Co chceme od termokamer, aby se daly používat masově. Amper (online). http://amper.ped.
muni.cz/jenik/LW-infrared/termokamery_co_chtit.html (Accessed Mar. 26, 2019).

3. Anon. n.d.d: Datalogger ALMEMO ${ }^{\circledR} 710$. Ahlborn (online). https://www.ahlborn.cz//out/pictures/wysiwigpro/ ALMEMO_710CZ.pdf (Accessed Mar. 26, 2019).

4. Anon. n.d.b: Termokamera flir E40BX, E50BX A E60BX. Flir (online). https://www.termokamery-flir.cz/ termokamera-flir-e40bx-e50bx-e60bx/ (Accessed Apr. 21, 2018).

5. Anon. n.d.a: Window Types and Technologies. Energy. gov, Washington, DC (online). https://www.energy.gov/ energysaver/window-types-and-technologies (Accessed Nov. 26, 2018).

6. Baldinelli, G.; Asdrubali, F.; Baldassarri, C.; Bianchi, F.; D’Alessandro, F.; Schiavoni, S.; Basilicata, C., 2014: Energy and environmental performance optimization of a wooden window: A holistic approach. Energy and Buildings, 79: 114-131.

https://doi.org/10.1016/j.enbuild.2014.05.010.

7. Bossche Van Den, N.; Buffel, L.; Janssens, A., 2015: Thermal Optimization of Window Frames. Energy Procedia, 78: 2500-2505.

https://doi.org/10.1016/j.egypro.2015.11.251.

8. Černíková, M.; Oravec, P.; Panovec, V., 2012: Measuring of thermophysical properties of window panes after five years of using. Ostrava. Sborník vědeckých prací Vysoké školy báňské - Technické univerzity Ostrava.

9. Gustavsen, A.; Grynning, S.; Arasteh, D.; Jelle, B. P.; Goudey, H., 2011: Key elements of and material performance targets for highly insulating window frames. Energy and Buildings, 43: 2583-2594. https://doi.org/10.1016/j.enbuild.2011.05.010.

10. Hollan, J., 2005: Termografické ověřování tepelně izolačních vlastností oken se speciálními roletami. Příspěvek k dílně Nedestruktivní testování v technických oborech, FAST VUT v Brně, pp. 25-27.

11. Motyková, A., 2008: Okna: správná řešení pro novostavby i rekonstrukce. Praha. Grada.

12. Schneck, A., 2001: Okna dřevěná a kovová. Brno, ERA.

13. Slanina, P., 2012: Nejnižší povrchová teplota výplní otvorů. Časopis Stavebnictví, 06-07: 28-34.

14. *** ČSN EN ISO 13788, 2002: Hygrothermal performance of building components and building elements Internal surface temperature to avoid critical surface humidity and interstitial condensation - Calculation methods. Praha. Český normalizační ústav.

15. *** ČSN EN ISO 10077-1, 2007: Thermal performance of windows, doors and shutters - Calculation of thermal transmitance. Praha. Český normalizační ústav.

16. *** ČSN 730540-2, 2002: Thermal protection of buildings. Part 2: Requirements. Praha. Český normalizační ústav.

\section{Corresponding address:}

Assoc. Prof. PAVEL KRAL, PhD

Mendel University in Brno

Faculty of Forestry and Wood Technology

Zemědělská 1, 61300 Brno, CZECH REPUBLIC

e-mail:kral@mendelu.cz 